SANJA STEINER, Ph.D.

E-mail: tmihetec@fpz.hr

ANA BOŽIČEVIĆ, Ph.D. candidate

E-mail: anab@fpz.hr

University of Zagreb,

Faculty of Transport \& Traffic Sciences

Vukelićeva 4, Zagreb, Croatia

\title{
PROSPECTS OF AIR TRAFFIC MANAGEMENT IN SOUTH EASTERN EUROPE
}

\section{ABSTRACT}

In the forthcoming period the European air traffic management will handle double flight operations than today - from 1.7 to 2.1 higher traffic level in 2025 than in 2005 [1]. The problem of the European airspace fragmentation should be solved by the comprehensive dynamic harmonization programs, which can contribute to effective increase of airspace capacity and increase of air transport efficiency. The main objective of the development strategy refers to the implementation of reformation processes of the European air traffic management system through functional ATM $^{1}$ regionalization. Encouraged by the Single European Sky project, and through airspace de-fragmentation, numerous projects have been initiated by Eurocontrol in cooperation with the European Commission. One of them is establishing of the Functional Airspace Block in South Eastern Europe. The implementation of regulatory, institutional and legal framework of the Single European Sky FAB ${ }^{2}$ would ensure the expansion of the European air traffic market to South Eastern Europe, counting over 500 million potential users [2]. Croatia and all the other countries in the region have to adopt the provisions of ECAA ${ }^{3}$ Agreement and EU air transport acquis in their national legislation.

This paper specifies the main determinants of the strategic development as well as the key factors which influence the European air traffic dynamics. The paper elaborates the indicators and significant elements of the required ATM reforms in South Eastern Europe on the samples of six ANSPs according to ECAA Agreement and EU acquis.

\section{KEYWORDS}

Single European Sky, European Common Aviation Area, Air Traffic Management, South Eastern Europe, Functional Airspace Block

\section{INTRODUCTION}

The regulatory environment of the aviation industry has significantly changed over the last two decades. The origins of these changes lie in the aviation industry liberalization. The 1978 United States Deregulation Act was the most important event in the worldwide aviation market, changing the face of civil aviation in the United States. The required permission for airlines to serve any given route was dismantled with the Deregulation Act. As it followed, Europe launched its three Liberalisation Aviation Packages during last two decades, gradually liberalised the aviation market of the member countries [3]. Air transport had been traditionally a highly regulated industry, performed dominantly by national flag carriers and state-owned airports. The internal market has removed all commercial restrictions for airlines flying within the European Union, such as restrictions on the routes, the number of flights or the setting of fares, while that is not the case when flying to countries outside $\mathrm{EU}^{4}$. The creation of the single European market brought significant benefits to airspace users. Since 1993 the number of airline routes has increased by 170 percent within EU, ensuring greater choice of destinations and direct flights for passengers. Between 1993 and 2006, the number of routes with more than two carriers rose by 300 percent [4]. Due to the EU enlargement in 2004, the air traffic in accession countries doubled in just two years.

International aviation has traditionally been governed by bilateral agreements between individual countries, restricting the number of airlines on the routes concerned, the number of flights and the possible destinations. In order to overcome this limitation the European Community is extending its policy over its borders. In June 2005 transport ministers agreed on a roadmap for the development of external aviation policy. The extension of a single market to neighbour- 
ing countries is a key EU objective. As the objective of EU external policy is the creation of Common Aviation Area by 2010, in June 2006 the ECAA agreement was signed. This agreement integrates partner countries in South Eastern Europe - (Albania, Bosnia and Herzegovina, Croatia, Macedonia, Montenegro, Serbia, and Kosovo) into a single market [5]. The ECAA partner countries will adopt the EU air transport regulations.

A competitive and sustainable air transport industry needs a high performance ATM system. This will be achieved by the integration of the European airspace by means of dynamic harmonisation programmes [6]. The strategic development programmes of the European airspace refer to the solving of the problem of fragmented airspace by means of ATM regionalisation, increasing airspace capacity and traffic efficiency [7]. Thus the 2004 adaptation of the Single Sky legislation brought legal basis for a range of activities in the ATM system. The European Commission has mandated Eurocontrol to provide technical assistance and develop the implementing rules within the SES ${ }^{5}$ framework. The technological dimension of SES has been articulated by SESAR ${ }^{6}$, speeding up the innovations in aviation industry. The fragmentation issue will be solved through the Functional Airspace Block concept, where air traffic would be based on operational requirements, regardless of the existing boundaries [8].

\section{REGULATORY ENVIRONMENT IN SOUTH EASTERN EUROPE}

The European air transport sector which can be defined as airports, airlines, Air Traffic Management and the manufacturing industry, comprises more than 130 airlines, operating across over 450 airports with some 60 air navigation service providers. Air transport sector represents a complex and unique global network linking people, playing a vital role in further integration and development of the enlarged Europe. Air transport makes a contribution to the European economy with more than 3 million people employed in the EU and a contribution of EUR 120 billion to the European GDP. According to Eurocontrol $\mathrm{CFMU}^{7}$ data, there are on the average 28,000 flights on a daily basis in Europe. The number of flights in Europe reached in 2008 an all time high (over 10 million flights), the peak being with 34,476 flights. The growth under the ECAA Agreement counted over 6.6 million passengers travelling between the EU and the South Eastern Europe in 2007 (a 5\% increase over the 2006 figures) [9].

The extension of the European air transport market in South Eastern Europe will have positive outcome on the business travelling, tourism and broader integration of the region. With full implementation of the ECAA Agreement by the year 2010, the countries of South Eastern Europe will become a part of fully inte- grated aviation market with 500 million potential passengers [10].

The European Investment Bank in cooperation with the Nordic Aviation Resources launched in 2000 the Air Traffic Infrastructure Regional Study which served as the basis for investment project in the transport sector. The key findings were presented as: differences in aerospace organisation in the countries, lack of integration of the ATM infrastructure in the region (as area control centres and non optimal routes and sectors are designed to meet national requirements), large amount of airspace used for military purposes, insufficient interoperability as result of national industrial interests in investment decisions (area control centres have limited technical and operational compatibility with neighbours), shortage of air traffic controllers in the region, on-job training as result of very diverse environment (design and equipment of area control centres) [11].

Membership of South Eastern European countries in the European institutions has to be observed in order to analyse the Institutional framework of air traffic control and aviation safety in the SEE Region. The $\mathrm{ICAO}^{8}$ and the $\mathrm{ECAC}^{9}$ define the safety and the security standards for their members, audit compliance and provide training. All countries analysed are members of four European institutions with complementary mandates addressing cross-border issues in air traffic control safety and security. All countries observed are members of $\mathrm{JAA}^{10}$ even though most of its functions are delegated to $E A S A^{11}$, except the liaison between EASA and $C A A^{12}$ of non EASA JAA member states and for training functions. EASA competences have been expanded to safety regulation of aerodromes, air traffic management and air navigation services, and for the total system approach to civil aviation safety ${ }^{13}$. All SEE countries participate in the work of Eurocontrol which is mandated to integrate air traffic control across Europe. Eurocontrol provides technical expertise for aeronautics and flight across Europe and is working on the building of a homogenous Pan European air traffic management system. Eurocontrol CFMU ${ }^{14}$ manages the flow of 44 states which participate in ECAC in order to ensure that the user demand does not overload the capacities of the existing infrastructure. Eurocontrol $\mathrm{CRCO}^{15}$ provides Pan European cost-recovery system that funds air navigation facilities and services and supports Air Traffic Management developments. Eurocontrol manages Aviation Safety and Traffic Control II project, which provides assistance to countries in order to fulfil the future international, regional and national responsibilities, aligning their national ATM systems with the European standards. The support is focused on the development of effective and efficient Civil Aviation in each of the five CARDS $^{16}$ countries. The projects are funded by the EU [12]. 


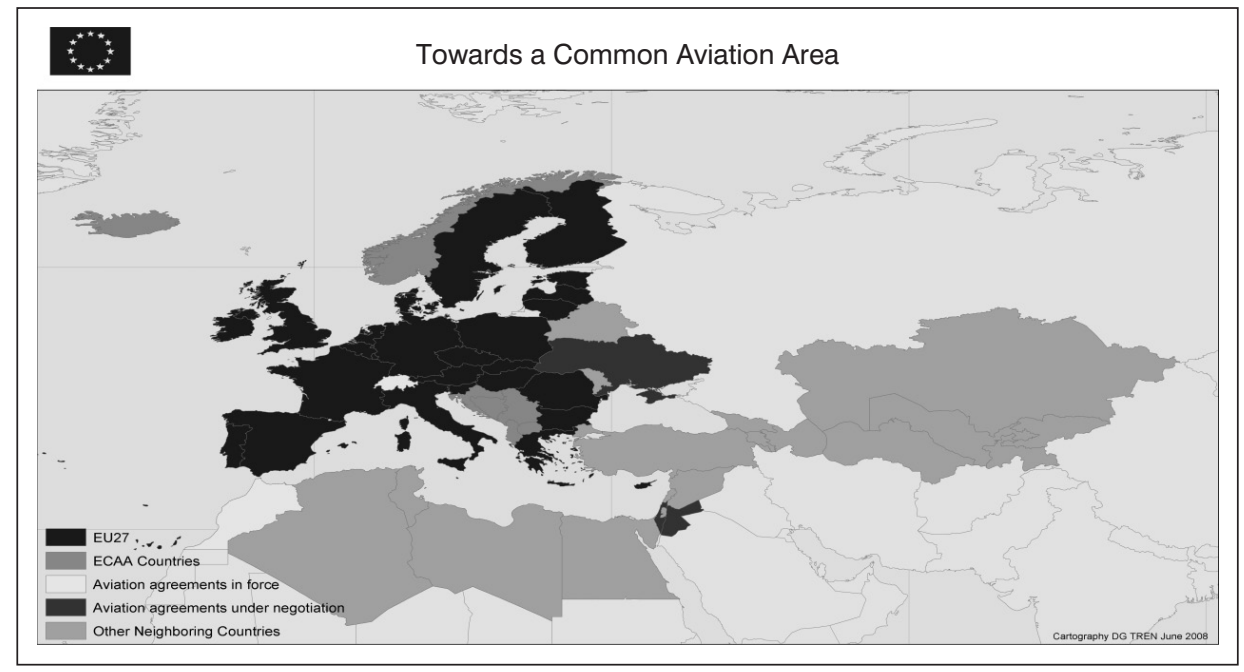

Figure 1 - Common Aviation Area, 2009

Source: http://ec.europa.eu/transport/air/international_aviation/doc

In order to reorganise the international market policy that is based on bilateral agreements granting the traffic rights, EU has developed external aviation policy with the aim of creating economic opportunities by opening new markets for the competition and ensuring fair competition by promoting regulatory convergence in key areas. When dealing with different countries the Community approach needs to be done on case-bycase basis (maturity of the market, level of ambitions of the country concerned, level of harmonisation with EU regulations and standards and specific interests of the Community and member country. The External policy will be achieved through three pillars: a) ensuring the legal certainty of the existing bilateral agreements between EU member countries and third countries (since 2004 more than 700 bilateral agreements have been brought into conformity with the Community law), b) negotiating comprehensive $\mathrm{ATA}^{17}$ on EU level with certain third countries (such agreements create new economic opportunities for the European air transport industry and regulatory convergence process ensuring fair competition at level playing field beyond the scope of traditional air transport agreements - e.g. Open Sky Agreement with US, c) developing a Common Aviation Area with the neighbouring countries by 2010 - e.g. Union for the Mediterranean and ECAA).

The beginning of the CAA can be traced back to 1993, when the most advanced integration of the third countries with the EU air transportation policy was achieved within the framework of the European Economic Area Agreement ${ }^{18}$. The EU and ten neighbouring countries $^{19}$ have agreed to establish a European Common Aviation Area by 2010 (Figure 1). The extension of the European air transport market on South Eastern European countries should have positive outcome on tourism, business travel and broader integration of the region [13]. The ECAA Agreement was signed in June
2006 and commits all signatories to adopt the EU acquis for air transport, which includes:

- legislation that liberalizes market access, traffic rights and fares;

- regulation on airport ground handling and slot allocation;

- safety and security regulations;

- rules on competition and state aid;

- the acquis related to air traffic management and the Single European Sky; and

- environmental standards and consumer rights pertaining to aviation.

The implementation of the ECAA Agreement will take place in three stages. In the first stage all carriers licensed within ECAA will be able to fly from their countries to any ECAA destination $\left(3^{\text {rd }}\right.$ and $4^{\text {th }}$ freedom right). The second stage will allow airlines to pick up passengers on stop-over flight before dropping them to a third country $\left(5^{\text {th }}\right.$ freedom). Third stage liberalises the market by acceptance of all the remaining freedoms and full transposition of the aviation acquis. ECAA presents vehicle for cross-border agreement and has significant advantages over an open sky approach:

- only one agreement is needed instead of a revision of several dozen ATAs;

- induces countries to modernise their sector policies in line with international best practices;

- harmonises regulatory framework and increases transparency for market participants; and

- ensures the development of regional route networks ${ }^{20}$.

The ECAA agreement obliges countries signatures of the agreement on the adaptation of about two dozen of EU Regulations and Directives ${ }^{21}$. The issue arising from the implementation of the EU Law is evident when governments have to discontinue restrictive practices related to traffic rights and price controls. 
Table 1 - Compliance with Selected Elements of the Aviation Acquis,

\begin{tabular}{|c|c|c|c|c|c|}
\hline & Albania & $\begin{array}{c}\text { Bosnia\& } \\
\text { Herzegovina }\end{array}$ & Croatia & FYROM & Serbia \\
\hline licensing & no & no & yes & No & n.a \\
\hline fares & no & no & no & partial & n.a \\
\hline market access & no & no & partial & No & n.a \\
\hline safety & no & no & partial & partial & partial \\
\hline environment & no & no & partial & partial & partial \\
\hline consumer protection & no & partial & no & No & partial \\
\hline ground-handling & no & no & no & No & no \\
\hline slot allocation & no & no & no & No & no \\
\hline air traffic control & no & no & partial & partial & no \\
\hline state aid & no & no & partial & No & no \\
\hline
\end{tabular}

Source: Based on analysis of the European Commission/Bozz Allen Hamilton

Table 2 - Establishment of the NSA and certification of the ANSP

\begin{tabular}{||l|l|l||}
\hline \multicolumn{1}{|c|}{ Country } & \multicolumn{1}{c||}{ NSA } & \multicolumn{1}{c||}{ ANSP } \\
\hline \hline Albania & Established - Institutional separation & Not certified \\
\hline Bosnia \& Herzegovina & Not established & Not certified \\
\hline Croatia & Established - Institutional and functional separation & Certificated $^{23}$ \\
\hline FYROM & Established - Functional separation & Certification planned during 2009 \\
\hline Kosovo & Established - Institutional and functional separation & Not certified \\
\hline Montenegro & Established - Institutional separation & SMATSA is providing ANS \\
\hline Serbia & $\begin{array}{l}\text { Established - Institutional, function- } \\
\text { al and organisational separation }\end{array}$ & Not certified \\
\hline
\end{tabular}

Source: Own research, LCIP Eurocontrol

On the other hand, EU rules apply only beyond certain thresholds that most countries in the region do not yet cross. The alignment of national legislation with the ECAA Agreement entails substantial reforms [3].

Most of the countries have started to make adjustments to their national legislation concerning aviation, but the process of the establishment of the ECAA is still a long way to go (see Table 1). The acceleration of the adjustment with ECAA Agreement could be achieved by the introduction of clauses in aviation codes which would permit the introduction of new national laws in direct reference to international regulation. The main issue of ECAA implementation is the willingness of governments in the concerned countries.

The institutional framework of the aviation sector requires further adjustment. According to international best practices, the aviation policy is the responsibility of transport ministries, while autonomous Civil Aviation Authority (CAA) should be in charge of safety and economic regulation. The CAA should be given full political and institutional independence. The SES I legislation requires the establishment of the National Supervisory Authority (NSA) which should be at least functionally if not institutionally separated from the Air Navigation Service Provider (ANSP). Since June 2007 the ANSP have become subject to certification (common requirements) by the NSA ${ }^{22}$.

As the requirement of the EU transport acquis, the air traffic control should be handled by separate autonomous entity. Other operational functions - such as airlines, airport, ground handling services - should be separated from the ministry and the regulator and if possible commercialised and where possible privatised. In the South Eastern Europe substantial work remains to be done (see Table 2) [14].

Ambitious initiatives for regional ATM cooperation have been launched. Given the fragmentation of airspace above SEE, regional ATM cooperation needs to complement reforms at the national level. Airplane travelling at $900 \mathrm{~km} / \mathrm{h}$ needs less than 10 minutes to cross the Macedonian and 20 minutes to cross the Bosnian airspace. On some regional routes, airplanes fly across five different countries in the course of an hour. There is no unique solution for regional ATM cooperation and for the achievement of a seamless and cost-effective ATM system. According to SES Framework Regulation the establishment of Functional Airspace Blocks should organize airspace regardless of national boundaries based on operational requirements enabling cross-border provision of air naviga- 
tion services. The first such project in the region was CEATS $^{24}$, where the objective was the development of consolidated facility for air traffic services provision. The second approach for harmonizing the regional ATM cooperation was the SEE FAB ${ }^{25}$ approach, proposed by the European Commission and the Stability Pact, in cooperation with Eurocontrol. The SEE FAB approach no longer exists and it is replaced by ISIS $^{26}$ which will provide the support to help the transposition of SES regulations to national law. ISIS will help the regional members of ECAA to comply their obligations in the field of Air Traffic Management. The most recent approach towards regional cooperation is presented through the establishment of FAB Central Europe as the successor of the CEATS project. The implementation of FAB CE will improve the performance in the following key areas: increase in capacity to cope with increase of around 60 percent in 2017 with a minimum delay of 0.3 minutes per flight in 2017, improved en-route financial cost effectiveness by $5 \%$ in 2017 compared with 2006, concerning flight efficiency there should be a saving of 2 million $\mathrm{km}$ annually by 2017 onwards, and reduced environmental impact by 22 million tons of CO2 annually by 2017 onwards [15].

\section{OPERATIONAL ASPECT OF REGIONAL AIR TRAFFIC}

Air traffic is growing rapidly from a low base, as a shadow of a series of armed conflicts and economic turbulences of the past decades. Traffic growth in South Eastern Europe can be described by two characteristics. The first one is that the main drivers of passenger traffic in the region are tourism and the migrant communities. The second characteristic is that much of the passenger traffic between the EU and South Eastern Europe is land based. Air transport in the SEE is driven by GDP growth and exponential relationship between per capita income and the tendency to fly.

The Eurcontrol medium term report (which includes over-flight traffic) assumes an annual 4-percent growth for the selected countries between 2008 and 2015, while the base case scenario for EU 27 predicts 1.9 percent annually. The main drivers for air transport demand in SEE region are tourists (mostly EU nationals) and large migrant community (mostly based in EU). Eurocontrol flight movements forecast (2009-2015) emphasizes that route network sensitivity will be concentrated in South Eastern Europe because the reduction in IFR ${ }^{27}$ departures is not connected with the influence and effects of high-speed trains [9]. The main characteristic of air traffic in the region is that the majority of traffic flow in the SEE Region flows across national borders, as most countries are too small for domestic flights. Croatia is the only exception, with 554,000 passengers in domestic traffic. The second characteristic is that the regional air traffic flows account for two-thirds of air traffic in the SEE Region - 69 percent in Bosnia and 87 percent in Albania. Albania and Kosovo have only one airport each, while FRY of Macedonia has two, which are $150 \mathrm{~km}$ apart. This highlights the importance of cross-border liberalisation - ECAA. The third characteristic is strong migration and trade linkages with the neighbouring countries. Germany, Italy and Austria, according to the EC Report, account for over 60 percent of the routes from EU to South Eastern Europe. At the same time the low-cost effects and market share by traffic zone will be in 2015 the lowest in Albania (5\%) and Macedonia (8\%), modest in Serbia-Montenegro and Bosnia-Herzegovina (19-20\%) and the highest in Croatia (21-30\%). It should be noted that on the Croatian air transport market in terms of carried passengers the share of LCC (year 2008) is already 24.8 percent.

There are some 2,000 airlines around the world that operate a total fleet of 23,000 aircraft. They serve some 3,750 airports through a route network of several million kilometres managed by around 160 air navigation service providers [16]. The South Eastern European region represents a modest and undeveloped region, which represents 0.59 percent of passenger transportation in the world scheduled air traffic and 0.53 percent of international airports in the world. General indicators of air traffic development in 2008 are presented in Table 4. The indicator number of passengers carried per capita indicates the degree of the

Table 3 - Regional forecast traffic growth (2008-2015)

\begin{tabular}{||l|c|c|c|c||}
\hline \multirow{2}{*}{ Country } & \multicolumn{2}{c|}{ base case } & \multicolumn{2}{c||}{ high case } \\
\cline { 2 - 5 } & annual & total & annual & total \\
\hline \hline Albania & 3.4 & 26.3 & 5 & 50.7 \\
\hline Bosnia \& Herzegovina & 4.1 & 32.4 & 6.1 & 49.3 \\
\hline Croatia & 4 & 31.5 & 5.9 & 49.3 \\
\hline FRYOM & 4.9 & 39.7 & 5.9 & 48.4 \\
\hline Serbia \& Montenegro & 4 & 31.5 & 5.8 & 47.8 \\
\hline \hline Regional Average & 4.08 & 32.28 & 5.74 & \\
\hline
\end{tabular}

Source: Eurocontrol, Medium Term Forecast, 2009 
Table 4 - General air transport indicators in the South Eastern Europe

\begin{tabular}{|c|c|c|c|c|c|c|c|}
\hline \multirow{2}{*}{ Country } & \multicolumn{3}{|c|}{$\begin{array}{c}\text { Passengers } \\
(000)\end{array}$} & \multirow{2}{*}{ Cargo $000 \mathrm{t}$} & \multirow{2}{*}{ Airports } & \multirow{2}{*}{ Airlines } & \multirow{2}{*}{$\begin{array}{c}\text { Passengers } \\
\text { per Capita }\end{array}$} \\
\hline & $\begin{array}{c}\text { Interna- } \\
\text { tional }\end{array}$ & Domestic & Total & & & & \\
\hline Albania & 1,267 & 0 & 1,267 & 3,5 & 1 & 4 & 0,4 \\
\hline Bosnia\& Herzegovina & 550 & 0 & 550 & 1,5 & 3 & 1 & 0.15 \\
\hline Croatia & 4,610 & 554 & 5,164 & 13,9 & 8 & 4 & 1,15 \\
\hline FYROM & 697 & 0 & 697 & 2,8 & 2 & 1 & 0.34 \\
\hline Montenegro & 1,109 & 0 & 1,109 & 0.8 & 2 & 1 & 1,85 \\
\hline Serbia & 2,680 & 0 & 2,680 & 7,2 & 2 & 2 & 0,36 \\
\hline Kosovo & 1,131 & 0 & 1,131 & 1,0 & 1 & & 0,6 \\
\hline Total/Average & 12,470 & 554 & 13,024 & 29,9 & 19 & 13 & 0,87 \\
\hline
\end{tabular}

Source: Own research; Steiner, Tatalović, Bajić

Table 5 - Primary airports in the SEE region

\begin{tabular}{||l|c|c|c|c|c||}
\hline \multirow{2}{*}{ Airport } & \multicolumn{3}{|c|}{ Passengers } & \multirow{2}{*}{ Index 08/06 } & Runway length \\
\cline { 2 - 6 } & 2008 & 2007 & 2006 & 119 & 3,400 \\
\hline \hline Belgrade & $2,650,048$ & $2,512,890$ & $2,222,445$ & 127 & 3,252 \\
\hline Zagreb & $2,192,453$ & $1,992,445$ & $1,728,413$ & 140 & 2,750 \\
\hline Tirana & $1,267,041$ & $1,107,325$ & 906,103 & 110 & 2,550 \\
\hline Split & $1,203,778$ & $1,190,551$ & $1,095,852$ & 106 & 3,300 \\
\hline Dubrovnik & $1,191,474$ & $1,143,168$ & $1,120,453$ & 128 & 2,500 \\
\hline Prishtina & $1,130,640$ & 990,259 & 882,731 & 120 & 2,450 \\
\hline Skoplje & 652,339 & 626,644 & 542,319 & 135 & 2,500 \\
\hline Tivat & 608,000 & 574,011 & 451,289 & 109 & 2,600 \\
\hline Sarajevo & 506,398 & 505,269 & 466,186 & 131 & 2,500 \\
\hline Podgorica & 501,113 & 460,020 & 381,847 & 123 & \\
\hline \hline TOTAL: & $11,903,284$ & $11,102,582$ & $9,797,638$ & 116 & 3,600 \\
\hline \hline Vienna & $19,747,289$ & $18,800,000$ & $17,000,000$ & & 123 \\
\hline \hline
\end{tabular}

Source: Own research; Steiner, Tatalović, Bajić

development and mobility of the population [17]. The leaders in the region are Montenegro (whose residents traditionally use air transportation services) and Croatia which has domestic air transport market, unlike other countries in the region.

In order to observe air transportation in the SEE region it is necessary to observe the number and categories of airports. Traffic, economic and political criteria for categorisation of airports starts from the capitals and the main cities of the region, together with minimum traffic volume of at least 500,000 passengers a year. The SEE region currently has 19 commercial airports with scheduled air traffic. Many airports in the region are close enough to national borders to serve parts of the neighbouring countries (Mostar airport lost much of its traffic to nearby Split and Dubrovnik). Zagreb and Belgrade represent the main airports with connecting flights in the region, but there is no central hub. Vienna, Milan and Munich airport provide hub services to the SEE region. With 2.6 and 2.2 million pas- sengers in 2008 Zagreb and Belgrade airport remain small by European standards. Combined air transport on primary airports of the region counts approximately 12 million passengers while Vienna international airport alone handled 19.7 million passengers in 2008. The main implications for airport development are small national aviation markets across the region and geographical location of many airports. Also, the competition among the airports with overlapping hinterlands can be fostered by improving road and rail links and cross-border procedures. Investment cost can be minimised if airport development is coordinated at the regional level. In order to achieve regional level of cooperation, national transport ministers and the European Commission signed a Memorandum of Cooperation for the SEETO ${ }^{28}$, which identified eleven priority airports ${ }^{29}$ [18]. Most of the airports in the EU are already privately owned, including London, Brussels, Vienna and Rome. The EU acquis does not include any provisions regarding the privatisation of airports 
Table 6 - Dominant airlines in SEE region

\begin{tabular}{|l|r|l|r|r|r|r|r||}
\hline \multicolumn{1}{|c|}{ Airline } & $\mathrm{N}^{\mathrm{o}} \mathrm{a} / \mathrm{c}$ & \multicolumn{1}{|c|}{ Aircraft Types } & Routes & $\begin{array}{c}\text { Passengers } \\
(000)\end{array}$ & $\begin{array}{c}\text { Index } \\
\text { 08/07 }\end{array}$ & $\begin{array}{c}\text { PLF } \\
(\%)\end{array}$ & Employees \\
\hline \hline Albanian Airlines & 4 & 3 Bae 146; 1 MD 82 wl & 4 & 220 & 110 & 51 & 165 \\
\hline B\&H Airlines & 2 & 2 ATR 72 & 6 & 73 & 107 & 66 & 90 \\
\hline Croatia Airlines & 10 & 4 A320, 4 A319, 2 Q400 & 43 & 1,869 & 109 & 65 & 1,114 \\
\hline Macedon. Airlines & 2 & 2 B737 & 7 & 215 & 96 & 71 & 159 \\
\hline Monteneg. Airlines & 6 & 5 FOKKER 100; 1 EMB 195 & 11 & 498 & 107 & 64 & 409 \\
\hline JAT & 15 & 10 B737, 5 ATR72 & 37 & 1,330 & 103 & 62 & 1,697 \\
\hline TOTAL & 39 & & 108 & 4,205 & 105 & 63 & 3,634 \\
\hline Austrian Airlines & 99 & $\begin{array}{l}\text { A319, A320, A321, B737, } \\
\text { B767, B777, Fokker, Bombar. }\end{array}$ & 114 & 10,716 & 101 & 74 & 7,914 \\
\hline
\end{tabular}

Source: Own research; Steiner, Tatalović, Bajić

and airlines. The trend towards airport privatisation is spreading further eastwards ${ }^{30}$.

Almost two decades ago, the main airline in the SEE region was the Yugoslavian flag carrier, JAT, with 5 million passengers annually. After the breakup of Yugoslavia, all former member countries have established their own flag carriers. Bosnia even had two flag carriers, until Air Srpska went bankrupt in 2003. Many other airlines that emerged in the process are too small to survive on their own on the European market [19]. With 4.2 million passengers flown in 2008 and 39 mainly small aircraft, all carriers in the region combined account for less than half of the size of the Austrian Airlines (Table 6).

The concept of the national flag carrier, which represents national sovereignty, is an outdated concept ${ }^{31}$. Most of the countries no longer have national air carriers, and most of them have been privatised. The ECAA provides the notion why national flag carriers are obsolete. First, theownership restrictions will be abolished $^{32}$. Second, strict competition rules and state aid rules will prohibit governments from subsidizing airlines $^{33}$. Third, new private carriers will emerge, once the level playing field is established ${ }^{34}$. Key determinants of regional network structures are code-sharing agreements and airline alliances. Star Alliance is the dominant player in the region.

\section{CONCLUSION}

Issues arising from ATM reforms in Europe are not sufficiently delegated to the powers of national regulatory authorities, primarily because of the number of norms that are developed at the Eurocontrol level, and not at the international regulatory level. In other words, national regulators are not obligated and have no responsibility in the implementation. On the other side, in the process of deregulation of air traffic in Europe and with the goal of commercialization of service providers, the national air traffic control systems in most transitional countries are transformed from government departments into autonomous commercial enterprises, where majority ownership remains with the state. As a successor of former governmental form, these enterprises have assumed the existing infrastructure and human potentials, with the primary function of commercial managing on the open market, while the regulatory function of ATM systems remains within the powers of the national regulator. Following the non-obligated legislation and transposed qualified personnel to ATM operative, national regulators cannot appropriately respond to the development needs in the ATM system because of insufficient administrative capacity. This issue is especially expressed in South Eastern Europe countries.

Analyzing the existing international regulation and practices, and with regard to condition of airports in transition South Eastern European countries, one of the possible solutions in institutionally-organizational sense is restructuring of public enterprises concerned with airport services and preparation for commercialization of airport operators and possible privatization. Managing the airport implies the establishment of certain private service providers in the segment of maintenance and ground handling, and other non-transport related activities.

In the process of commercialization and possible privatization of airport operators, it is essential that all administrative competences - from certification, safety oversight, environmental protection, and prevention of monopolistic behaviour on the market (airport fares), licensing of airport staff, to the creation of airport policy must remain under the responsibility of the regulator.

When analyzing today's and future owner structure within the carrier, professional and scientific analysis predict more intensive models of privatisation, which would proportionally reduce the influence of the state on the business of the carrier. With countering the competition by the low-cost carriers and with the af- 
firmation on the regional market of South Eastern Europe, the carriers in the region should consider the option of business merger in alliances or joining more national carriers and forming a unique multinational carrier.

The most important assumption for the realisation of the mentioned postulates of strategic development is the stability of the region, which was in the last decade more of an exception than a rule.

Unlike the managing characteristics of airports and air carriers, in which the state influence is decreasing, air traffic control is generally in state ownership. If analysing the ownership of air navigation service providers in Europe, the process of privatization of air traffic services is present only in Great Britain (NATS is the only ANSP in Europe that is fully privatised). ICAO is the proposer of the commercialization concept concerning air navigation service providers. During the last decades there has been a trend of establishing independent ATM service providers.

Restructuring the national authorities of air traffic control as service providers, whether commercialized or not, seeks the elaboration of many criteria, such as legal changes, separation of regulatory functions from the operator for avoiding conflict of interest and transparency of the commercial enterprise (business revision, business publications and annual reports). In Europe, most of the air traffic control systems are commercialised or commercialisation is underway.

The unique issue in strategic planning of ATM sys tems at a regional level is the dubious status of Eurocontrol, which has the dual function of a regulator and a service provider. Thus, reformation processes at national levels need to be accompanied by consistent transposition of the regulatory ATM domain under the EASA competence.

\section{Dr. Sc. SANJA STEINER}

E-mail: ssteiner@fpz.hr

TOMISLAV MIHETEC, dipl. ing.

E-mail: tmihetec@fpz.hr

ANA BožıČEVIĆ, dipl. ing.

E-mail: anab@fpz.hr

Sveučilište u Zagrebu, Fakultet prometnih znanosti

Vukelićeva 4, 10000 Zagreb, Republika Hrvatska

\section{SAŽETAK}

\section{PROJEKCIJA UPRAVLJANJA ZRAČNIM PROMETOM U JUGOISTOČNOJ EUROPI}

U predstojećem razdoblju sustav upravljanja europskim zračnim prometom opsluživat će dvostruki broj letnih operacija nego danas - od 1,7 do 2,1 puta višu razinu prometa u 2025. u odnosu na 2005. Problem fragmentiranosti europskog zračnog prometa mora biti riješen sveobuhvatnim programima dinamičke harmonizacije, koji mogu pridonijeti efektivnom povećanju kapaciteta zračnog prostora i efikasnosti zračnog transporta. Glavni cilj razvojne strategije odno- si se na implementaciju reformacijskih procesa europskog sustava upravljanja zračnim prometom putem funkcionalne ATM regionalizacije. Potaknuti projektom jedinstvenog europskog neba (SES), te defragmentacijom zračnog prostora, inicirani su brojni projekti Eurocontrola u suradnji s Europskom komisijom. Jedan od njih je uspostava funkcionalnog prostornog bloka u jugoistočnoj Europi (FAB SEE). Implementacija regulativnog, institucionalnog i pravnog okvira za SES FAB trebala bi osigurati ekspanziju europskog tržišta zračnog prometa na jugoistočnu Europu, obuhvaćajući više od 500 milijuna potencijalnih korisnika. Hrvatska i sve ostale zemlje u regiji moraju adoptirati odredbe ECAA sporazuma i EU acquisa u zračnom prometu u svojoj nacionalnoj legislativi.

Rad specificira glavne odrednice strategijskog razvoja, kao i ključne čimbenike utjecaja na dinamiku europskog zračnog prometa. Rad elaborira indikatore i znakovite elemente potrebnih reformi u jugoistočnoj Europi na uzorku šest davatelja usluga zračne plovidbe (ANSP) sukladno ECAA sporazumu i EU acquisu.

\section{KLUUČNE RIJEČI}

jedinstveno europsko nebo, europski zajednički zrakoplovni prostor, upravljanje zračnim prometom, jugoistočna Europa, funkcionalni prostorni blok

\section{REFERENCES}

1. ATM - Air Traffic Management

2. $\mathrm{FAB}$ - Functional Airspace Block

3. ECAA - European Common Aviation Area

4. EU - European Union

5. SES - Single European Sky

6. SESAR - Single European Sky Research Program

7. CFMU - Central Flow Management Unit

8. ICAO - International Civil Aviation Organisation

9. ECAC - European Civil Aviation Conference

10. JAA - Joint Aviation Authorities

11. EASA - European Aviation Safety Agency

12. CAA - Civil Aviation Authority

13. Regulation of the European Parliament amending Regulation (EC) No 216/2008 in the field of aerodromes, air traffic management and air navigation services and repealing Council Directive 06/23/EEC

14. CFMU - Central Flow Management Unit

15. CRCO - Central Route Charges Office

16. CARDS - Community Assistance for Reconstruction, Development and Stabilisation

17. ATA - Air Transport Agreements

18. The European Economic Area (EEA) was established on 1 January 1994 following an agreement between the member states of the European Free Trade Association (EFTA), the European Community (EC), and all EU member countries. It allows these EFTA countries to participate in the European single market without joining the EU.

19. All EU countries (including Bulgaria and Romania who acceded in January 2007), Iceland, Norway and all countries of the Western Balkans

20. To build regional route networks with hub-and-spoke structures, airlines must be able to obtain traffic rights 
to and from different countries that are complementary in terms of timing, capacity and frequency.

21. Annex II - The European Common Aviation Area and the Western Balkans: Domestic Reforms and Regional Integration in Air Transport

22. Commission Regulation (EC) No 2096/2005 of 20 December 2005 laying down common requirements for the provision of air navigation services

23. Own research: Certificated on 31st of March 2009 by the CAA (one day before NSA operalisation)

24. CEATS - Central European Air Traffic Services - Agreement was signed in 1997, between Eurocontrol and Austria, Bosnia and Herzegovina, Croatia, the Czech Republic, Slovakia, Hungary, Italy and Slovenia. The main mission was the opening of CEATS Upper Area Center in Vienna.

25. SEE FAB - South Eastern Europe Functional Airspace Block - on 1st of April 2005, the Directors of Civil Aviation Albania, Bosnia and Herzegovina, Bulgaria, Croatia, Romania, Serbia and Montenegro (at the time still joint country), the former Yugoslav Republic of Macedonia and the UN Mission in Kosovo decide to examine opportunities with a view to implementing the Functional Airspace Block Approach in SEE (SEE FABA initiative) in consistency with the rest of the European Air Traffic Management network.

26. ISIS - Implementation of the Single European Sky in the South Eastern Europe - emerges from the previous SEE FAB initiative.

27. IFR - Instrument Flight Rules

28. The Memorandum for the Development of the South Eastern Europe Core regional Transport Network signed in June 2004 sets out the requirements for cooperation, sharing information, improving performance, investment and institutional support among participants.

29. Priority airports include all the capital airports of countries and entities (Zagreb, Sarajevo, Banja Luka, Belgrade, Podgorica, Prishtina, Tirana and Skopje) as well as two coastal tourism airports in Croatia (Split and Dubrovnik) and a secondary airport in Serbia (Nis).

30. Tirana airport was concessioned to an international consortium in late 2004 . For a period of 20 years, the investors will pay $€ 21$ million in concession fees to the government, while keeping all airport charges. The consortium will also invest $€ 82$ million in the construction of a new terminal, a new cargo center, a 7-km access road and the modernization of existing facilities. The Macedonian government considers a similar approach for privatizing the two national airports. Stateowned Belgrade airport pursues a different model; it established a joint venture with a US investor for the construction and operation of a new cargo center and leased all shops and restaurants to a Swiss company.

31. Council Regulation (EEC) No 2407/92 of 23 July 1992 on licensing of air carriers

32. Nationals of all ECAA countries will be able to own airlines in any other ECAA country.

33. As part of the "third package of EU competition and state aid rules became applicable to the sector in the early measures' for air transport liberalization 1990s. EU competition and state aid rules are cross-sectoral and thus addressed through the Stabilization and Association process, instead of the ECAA.

34. The few private airlines that have been established in the SEE region remain small, such as Trade Air (Croatia), Albatros Airways (Albania), Air Varda (Macedonia) and Centavia (Serbia)

\section{LITERATURE}

[1] Mihetec, T., Božičević, A., Steiner, S.: "Air Traffic Management Reform in South Eastern Europe, ICTS, Portorož", Slovenia 2008

[2] Eurocontrol Performance Review Report: "Evaluation of Functional Airspace Block Initiatives and their contribution to Performance Improvement", Belgium 2008

[3] Directorate-General for Energy and Transport in the European Commission: “EU Air Transport Policy, Flying Togethe", Belgium 2007

[4] European Commission - World Bank, Office for South East Europe: "The European Common Aviation Area and the Western Balkans: Domestic Reforms and Regional Integration", Belgium 2007

[5] Multilateral Agreement between The European Community and its Member States with eight Balkan Partners: "Albania, Bosnia and Herzegovina, Bulgaria, Croatia, the Former Yugoslav Republic of Macedonia, Romania, Serbia and Montenegro and the United Nations Mission in Kosovo on the establishment of a European Common Aviation Area". Belgium 2006

[6] Steiner, S., Božičević, A., Mihetec, T.: "Determinants of European Air Traffic development, VIII Conference Telematics, Logistics and Transport Safety, Katowice", Poland 2008

[7] European Commission: "EU and Southeast Europe move closer to Single Aviation Market" Belgium 2006

[8] European Commission: "Building the Single European Sky through Functional Airspace Blocks: A mid-term report", Belgium 2007

[9] Eurocontrol Statfor: "Medium-Term Forecast Flight Movements (2009 - 2015) First Volume”, Belgium 2009

[10] Steiner, S., Galović, B., Radačić, Ž.: "Strategic Framework of Air Traffic Development". // PrometTraffic\&Transportation, Scientific Journal on Traffic and Transportation Research, 3; 157-167, Croatia 2008

[11] European Investment Bank: Air Traffic Infrastructure Regional Study for South Eastern Europe, Executive ATC Summary report, Luxembourg 2001

[12] European Comission: "Community Assistance for Reconstruction, Development and Stabilisation, Reports 2001-2009", Belgium 2009

[13] European Commission: "Common Aviation Area with the Neighbouring Countries by 2010 - Progress Report", Belgium 2008

[14] Eurocontrol, "Local Convergence Implementation Plans (2009-2013) of Albania, Bosnia and Herzegovina, Bulgaria, Croatia, the Former Yugoslav Republic of Macedonia, Romania, Serbia and Montenegro and the United Nations Mission in Kosovo", Belgium 2008

[15] Eurocontrol: "Functional Airspace Block Central Europe Master Plan", Belgium 2008

[16] Air Transport Action Group: "The economic and social benefits of air transport 2008”, 2008 
[17] Steiner, S., Tatalović, M., Bajić, J.: “Competition and cooperation on European Southeast Air Transport Market", Economic Integration, Competition and Cooperation, 2009 Croatia

[18] South East Europe Transport Observatory: "South East Europe Core Regional Transport Network Five Year Multi Annual Plan (2009-2015)", 2009
[19] Mišetić, I., Steiner, S., Tatalović, M.: “Airline Marketing Factors", Promet-Traffic\&Transportation - Scientific Journal on Traffic and Transportation Research. 19, 1; 11-19 (preliminary information, scientific), Croatia 2007 